granites; these areas, which are quite bare except where covered by occasional clumps of grass, are remarkable in being quite fresh, showing no signs of weathering or any other kind of alteration. The absence of laterite on such surfaces has been explained by Mr. Morrow Campbell, who has paid much attention to the conditions under which rocks become kaolinized and lateritized in the tropics. This writer considers that crystalline rocks must be altered before they can be lateritized, and also that the alteration necessary, generally kaolinization, can be produced only when the rocks have been for a long time continuously in contact with vadose water, i.e. in the zone of permanent saturation. ${ }^{1}$ Accordingly, the fresh surface rocks referred to above, not having been subjected to such conditions, remain unlateritized.

Uxiversity College, CArdifF.

F. Dixey.

October 4, 1920 .

AN UNDESCRIBED SPECIES OF TROCHILIOPORA.

SIR,-I desire to draw attention to a band of Chalk in Sussex, about 10 feet thick, near the base of the zone of Micraster coranguinum, in which an undescribed Polyzoon belonging to the genus Trochiliopora is very common. As this fossil appears to be confined to the said band of Chalk, and also owing to its abundance, it has proved to be a very useful local zonal guide fossil. The exact position in which it occurs in the Micraster coranguirum zone is as follows :-

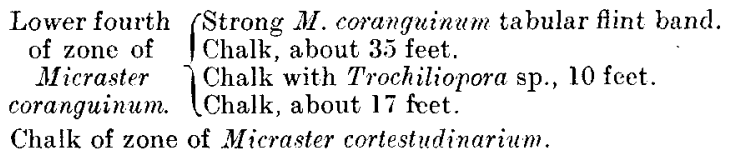

I propose to call the 10 feet of chalk referred to "the Trochiliopora bed"

The genus Trochiliopora has been described by Professor J. W. Gregory in the Grological Magazine, 1909, p. 65, and also in the British Museum Catalogue of Cretaceous Bryozoa, vol. ii, p. 265. The species above referred to resembles T. humei, Gregory, but its body tapers to a much finer stem than the stout blunt stem of the latter species.

The Trochiliopora bed is rich is Polyzoa, it having yielded some rare and interesting forms.

LEWES, SUSSEX.

Christopher T. A. Gaster.

October 4, 1920.

\title{
GEOLOGY OF THE NINGI HILLS.
}

Sir,--Major Williams' paper on the geology of the Ningi Hills of Nigeria in the October number is very welcome. It indicates not

1 Morrow Campbell, op. cit., p. 123. 
only an increasing interest by the mining community in the geology of the Nigerian tinfields, but also, I hope, an increasing disposition to publish geological observations thereon. Major Williams, however, will agree that in view of local controversies it is important that facts and conclusions should be correctly stated and deduced, and I may therefore perhaps be allowed to make the following remarks upon his paper.

Major Williams makes no mention of the fact that I mapped and described in 1911, in my "Geology and Geography of Northern Nigeria", the younger riebeckite-granites of Ningi, Kila, and Fagam, with which a portion of his paper is concerned. Of the country between Buji and Ningi, I have little personal knowledge, but from what $I$ have gathered in conversation with capable observers who have repeatedly traversed it, and from what I know of the adjoining parts of the tinfields, I feel sure that there are there not extensive outcrops of an older riebeckitic Sabon Garri granite, but a number of outcrops of younger riebeckite-granite projecting through older micaceous gneisses of various types. In spite of the assertion to the contrary in the appendix on p. 446, the petrographical descriptions do not confirm the hypothesis of an older series of intrusions "specially characterized by perthite, riebeckite, and ægirine". Of the sections quoted in support Nos. 106, 108, 110, C.C. 3 , and C.C. 4 contain no perthite, riebeckite, or ægirine; No. 113 is valueless as evidence; No. 115 is said on one page to be "slightly crushed" and on another to show "no sign of crushing" and to belong "to the younger series", while Nos. 100 and 105 are simply sections of normal younger granite.

It would also be interesting to know how Major Williams arrives at his belief that the younger granites of Nigeria are of Mesozoic age. It may be on account of the relative freshness of their outcrops, as in the case of the Tertiary (?) gabbro dyke of Keffi Filani. In any case the distinction of Archæan and Mesozoic soda-granites in Nigeria cannot be considered established, while the generalization that "tin is only found in granites that contain riebeckite" is true only in the sense that tinstone is associated with the younger granites, which may or may not carry riebeckite.

\section{LONDON.}

J. D. Falconer.

October $13,1920$.

\section{OBITUARY.}

\section{Sven Leonhard Törnquist, Ph.D., F.M.G.S.}

Bonn March 6, 1840.

Died September 6, 1920.

ThE study of Graptolites has in the last few years suffered the loss of some of its veteran workers, and to the names of Hopkinson and Lapworth must now be added that of the Swedish geologist, S. L. Törnquist. Born at Uddevalla in 1840 , he proceeded in due 